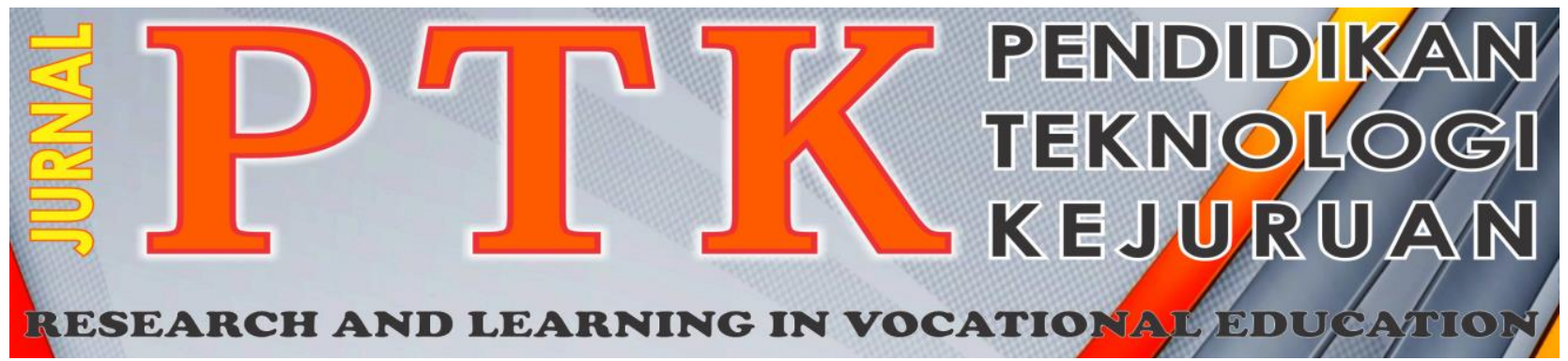

Vol. 2, No. 4, 2019

P-ISSN: 2621-3273

E-ISSN: 2621-1548

\title{
KONTROL LAMPU MENGGUNAKAN VOICE RECOGNIZER BERBASIS ANDROID
}

\author{
Irwan Yusti ${ }^{1}$ dan Asep Neris Bachtiar ${ }^{2}$ \\ ${ }^{1}$ Sistem Informasi, Sekolah Tinggi Teknologi Industri Padang \\ ${ }^{2}$ Teknik Pertambagan, Sekolah Tinggi Teknologi Industri Padang \\ Corresponding author e-mail: irwanyusti@sttind.ac.id
}

\begin{abstract}
Abstrak - Telpon seluler saat ini tidak hanya dapat digunakan untuk melakukan percakapan dan pengiriman pesan tetapi dapat juga digunakan untuk mengontrol peralatan elektronik. Penelitian ini bertujuan untuk mendayagunakan fasilitas pendeteksi suara yang ada pada android untuk mengontrol lampu.

Metode yang digunakan dalam penelitian ini adalah penelitian terapan untuk menghasilkan perangkat keras dan perangkat lunak yang dapat digunakan untuk mengontrol lampu. Perangkat keras berupa rangkaian elektronik berbasis Arduino sedangkan perangkat lunak merupakan aplikasi yang dapat dijalankan pada telpon seluler berbasis android.
\end{abstract}

Kata kunci : telpon seluler, pendeteksi suara, Arduino, Android

Abstract - Cell phones nowadays can not only be used for conversations and sending messages but can also be used to control electronic equipment. This study aims to utilize the existing voice detection facilities on Android to control the lights. The method used in this research is applied research to produce hardware and software that can be used to control lights. The hardware is in the form of an Arduino-based electronic circuit while the software is an application that can run on an Android-based cell phone.

Keywords: cell phone, voice detector, Arduino, Android

Copyright (C) 2019 JPTK. All rights reserved

\section{PENDAHULUAN}

Perkembangan teknologi telpon seluler yang sangat pesat membuat telpon seluler tidak hanya dapat digunakan untuk melakukan percakapan dan mengirim pesan tetapi dapat juga digunakan untuk fotograpi, memutar video dan menjelajah di jaringan internet. Dengan bertambahnya jenis komunikasi dalam telpon seluler seperti wifi, Bluetooth dan infra merah menjadikan telpon seluler sebagai perangkat yang dapat digunakan untuk mengontrol berbagai peralatan lain seperti Air Condisioner (AC), kamera, robot dan lain-lain.

Salah satu bentuk komunikasi yang sering digunakan adalah Bluetooth. Bluetooth merupakan salah satu teknologi komunikasi wireless (tanpa kabel) yang disediakan oleh sebagian besar telpon seluler. Komunikasi menggunakan Bluetooth beroperasi pada pita frekuensi $2,4 \mathrm{GHz}$ berdasarkan ISM (Industrial, Scientific and Medical) dengan menggunakan sebuah frequency hopping transceiver sehingga dapat digunakan untuk komunikasi data dan suara secara real time dalam jarak terbatas (maks 10 meter). walaupun komunikasi menggunakan Bluetooth memiliki kecepatan transfer data yang rendah tetapi tetap memiliki fitur -fitur keamanan sehingga dapat digunakan secara aman. Fitur-fitur yang disediakan Bluetooth antara lain : (1) Enkripsi data; (2) Autentikasi pengguna; (3) Lompatan frekuensi cepat (1600 hops/sec). 
Untuk dapat beroperasi dengan baik, telpon seluler dilengkapi dengan sistem operasi berbasis Android. Android merupakanperangkat lunak (software) yang sistem operasinya berbasis linux serta kode sumber terbuka (open source) yang di rancang untuk telpon seluler seperti tablet dan smartphone. Saat ini sistem Android juga digunakan pada mobil, tv, kamera, jam tangan dan perangkat lainya hal ini disebabkan karena sistem Android merupakan sistem operasi yang dapat disesuaikan dan mudah digunakan. Android secara komersial diperkenalkan pertama kali tanggal 20 Oktober 2008 pada smartphone HTC Dream.

Untuk dapat mengontrol lampu (hidup atau mati) diperlukan sebuah perangkat pengontrol. Perangkat pengontrol menggunakan Arduino. Arduino merupakan pengendali mikro single-board yang bersifat open source diturunkan dari Wiring platform. Arduino dirancang untuk memudahkan penggunaan elektronik dalam berbagai bidang. Penggerak utama dari Arduino adalah mikprosesor AtmelAVR dan perangkat lunaknya memiliki bahasa pemrograman sendiri yang memiliki kemiripan syntax dengan bahasa pemrograman C. Untuk fleksibilitas, program dimasukkan melalui bootloader meskipun ada opsi untuk mem-bypass bootloader dan menggunakan pengunduh untuk memprogram microcontroler secara langsung melalui port ISP

\section{METODE}

Metodologi yang digunakan dalam penelitian ini adalah penelitian terapan yang terdiri dari beberapa langkah yaitu :

1. Pembuatan rangkaian skematik

2. Pembuatan rangkaian papan tercetak (PCB)

3. Pembuatan perangkat lunak untuk Arduino dan telpon seluler

4. Uji coba

\section{HASIL DAN PEMBAHASAN}

\section{a. Blok Diagram}

Blok diagram merupakan gambaran dari alur kerja sebuah rangkaian elektronik, dari blok diagram dapat dilihat bagian-bagian dari sistem yang akan dibuat serta hubungan antara bagianbagian tersebut. Gambar blok diagram sistem kontrol lampu menggunakan voice recognizer seperti gambar 1 .

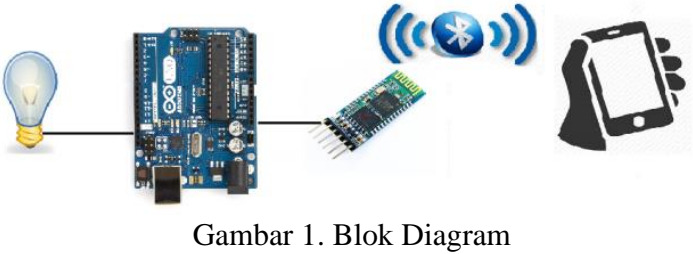

Dari gambar 1 dapat dilihat bahwa hubungan antara telpon seluler dengan pengontrol lampu menggunakan jaringan Bluetooth. Pada telpon seluler telah tersedia fasilitas untuk Bluetooth sedangkan pada Arduino ditambahkan sebuah perangkat yang dapat menerima sinyal Bluetooth yang dikirimkan dari telpon seluler.

\section{b. Gambar Skematik}

Gambar skematik merupakan gambar yang memperlihatkan komponen-kompoenen elektronik yang digunakan dalam projek serta hubungan antara komponen-komponen tersebut. Gambar skematik sistem kontrol lampu menggunakan voice recognizer seperti gambar 2.

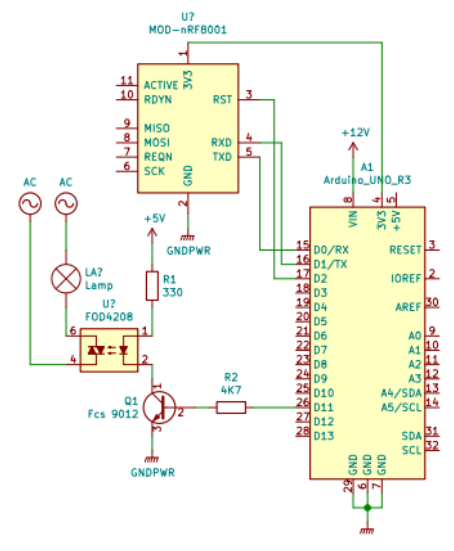

Gambar 2. Skematik Diagram

Dari gambar 2 dapat dilihat komponenkomponen elektronik yang digunakan untuk membangun sistem kontrol lampu menggunakan voice recognizer yaitu : (1) ArduinoUno; (2) Bluetooth; (3) opthocoupler; (4) transistor; (5) komponen penunjang. Prinsip kerja sistem kontrol lampu menggunakan voice recognizer sebagai berikut: (1) pengguna menyebutkan perintah pada aplikasi yang telah di tanamkan pada telpon seluler (hidup/mati); (2) aplikasi pada telpon seluler akan mengirimkan perintah tersebut melalui komunikasi Bluetooth; (3) Bluetooth pada Arduino menerima data yang dikirimkan oleh 
telpon seluler selanjutnya data tersebut di kirimkan ke Arduinouno; (4) data yang diterima di olah, selanjutnya menjadi perintah untuk menghidupkan atau mematikan lampu; (5) opthocoupler selain berfungsi sebagai isolator tegangan tinggi (tegangan $\mathrm{AC} 220 \mathrm{~V}$ ) juga berfungsi sebagai saklar elektronik yang akan menghidupkan atau mematikan lampu sesuai sinyal perintah yang dikirim oleh Arduino ( $5 \mathrm{~V}$ lampu mati dan 0V lampu hidup).

\section{c. Program Pada Telpon Selular}

Program pada sisi telpon seluler dibangun menggunakan aplikasi App Invetor yang dikembangkan oleh MIT. Rancangan antar muka sistem kontrol lampu menggunakan voice recognizer seperti gambar 3. Pada gambar rancangan dapat dilihat bahwa ada dua macam input perintah yang dapat digunakan (1) perintah menggunakan tombol yang terdiri dari tombol hidup dan tombol mati; (2) perintah menggunakan suara.

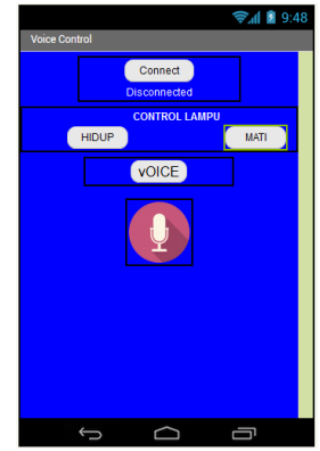

Gambar 3. Rancangan Antar Muka
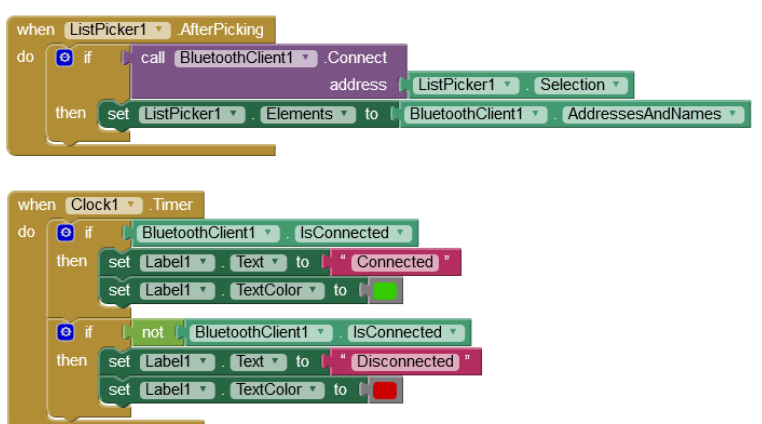

Gambar 4. Program Koneksi Bluetooth

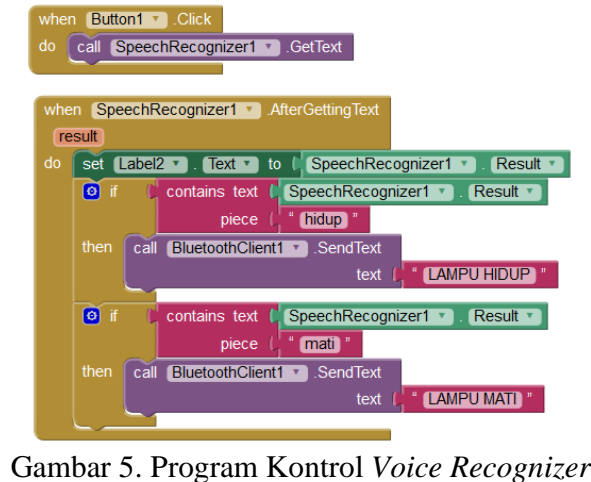

Gambar 4 merupakan program untuk menghubungkan Bluetooth pada telpon seluler dengan Bluetooth pada penerima, sedangkan gambar 5 merupakan program untuk mendeteksi suara dan mengirimkan perintah suara melalui Bluetooth.

\section{d. Program Pada Arduino}

void loop()

\{

bt.listen();

while (bt.available())

\{

inChar $=($ char $)$ bt.read () ;

if (inChar == '\#')

\{

if (inputdata == "LAMPU HIDUP")

\{

inputdata ="";

delay(1000);

digitalWrite(lampu, LOW);

\}

else if (inputdata == "LAMPU MATI")

\{

inputdata $="$ ";

delay(1000);

digitalWrite(lampu, LOW);

\}

(1)

else

inputdata $+=$ inChar:

\}

\}

Program diatas dapat dijelaskan sebagai berikut (1) Arduino menunggu data serial yang dikirimkan oleh Bluetooth; (2) ketika ada data serial maka nilai datanya akan dibandingkan dengan data yang telah ditentukan; (3) jika data yang diterima bernilai " LAMPU HIDUP” maka Arduino akan memberikan nilai 0 pada 
penggerak opthocoupler; (4) jika data yang diterima bernilai " LAMPU MATI" maka Arduino akan memberikan nilai 1 pada penggerak opthocoupler.

\section{e. Unjuk Kerja}

Untuk menggunakan aplikasi, pertama kali pengguna harus melakukan sambungan (pairing) antara Bluetooth pada telpon selular dengan Bluetooth pada penerima dengan cara menekan tombol connect selanjutnya akan tampil antar muka yang menampilkan nama-nama Bluetooth yang terdeteksi oleh telpon seluler. Pilih nama Bluetooth yang akan dihubungkan dengan telpon seluler.

Untuk mengirim perintah secara manual, tekan tombol hidup untuk menghidupkan lampu dan tekan tombol mati untuk mematikan lampu sedangkan untuk memerintahkan menggunakan suara terlebih dahulu tekan tombol voice lalu ucapkan kata "hidup" untuk menghidupkan lampu dan kata "mati" untuk mematikan lampu. Unjuk kerja sistem kontrol lampu menggunakan voice recognizer seperti tabel 1 .

Tabel 1. Unjuk Kerja Sistem Kontrol Lampu Menggunakan Voice Recognizer

\begin{tabular}{ccccc}
\hline $\begin{array}{c}\text { Jenis } \\
\text { Perintah }\end{array}$ & Perintah & $\begin{array}{c}\text { Data Yang } \\
\text { Terima }\end{array}$ & $\begin{array}{c}\text { Tegangan Basis } \\
\text { Transistor }(\mathbf{V})\end{array}$ & $\begin{array}{c}\text { Kondisi } \\
\text { Lampu }\end{array}$ \\
\hline \multirow{2}{*}{ Tombol } & Hidup & LAMPU HIDUP & 0 & Hidup \\
\cline { 2 - 5 } & Mati & LAMPU MATI & 1 & Mati \\
\hline \multirow{2}{*}{ Suara } & Hidup & LAMPU HIDUP & 0 & Hidup \\
\cline { 2 - 5 } & Mati & LAMPU MATI & 1 & Mati \\
\hline
\end{tabular}

\section{KESIMPULAN}

Sistem kontrol lampu menggunakan voice recognizer bekerja sangat baik pada jarak 5 meter dan akan berkurang performanya seiring dengan bertambahnya jarak antara telpon seluler dan perangkat penerima. Agar sistem kontrol lampu menggunakan voice recognizer dapat bekerja pada jarak yang jauh diperlukan jaringan komunikasi yang lebih baik seperti wifi dan perlu ditambahkan sensor untuk menentukan kondisi lampu serta pemberitahuan kepada pengguna apakah lampu dalam kondisi hidup atau mati.

\section{DAFTAR PUSTAKa}

[1] Arduino - Wikipedia bahasa Indonesia, ensiklopedia bebas.html

[2] Android - Wikipedia bahasa Indonesia, ensiklopedia bebas.html

[3] Bluetooth - Wikipedia bahasa Indonesia, ensiklopedia bebas.html

[4] Google Developer Training Team, 2016 "Andriod Developer Fundamentals Course, learn to develop Android Applications"

[5] http://Sejarah Android Dan Perkembangannya Lengkap Dari Awal Hingga Sekarang.html

[6] http://Apa Itu Android, Sejarah dan Versiversinya.html

[7] Massimo Banzi, Michael Shiloh, "Getting Started with Arduino" 